\title{
Research on China's Steel Demand Using Combined Forecast
}

\author{
Yuyan Weng ${ }^{1}$, Li Zhou ${ }^{1}$, Sheng Zhou ${ }^{1}$ and Tianyu $\mathrm{Qi}^{1}$ \\ ${ }^{1}$ Institute of Energy, Environment and Economy, Tsinghua University, Beijing, \\ China, 100084. \\ wengyy12@mails.tsinghua.edu.cn; zhoulizl@tsinghua.edu.cn; \\ zhshinet@mail.tsinghua.edu.cn; apollo110110@gmail.com
}

\begin{abstract}
This research conducts an error analysis between the forecasting value and the actual value of steel demand of 2010 in China, which is based on the analysis of forecasting methods and their results of Chinese steel demand in the existing studies, and then forecasts China's steel demand in 2015 by making use of a combined forecasting method. The combined forecasting method includes two stages. In the first stage, with reference to actual steel demand of China in 2010, a threshold is set and some forecasting results are selected according to the error between the forecasting value and actual value of steel demand of each method. In the second stage, weights of corresponding selected methods are determined which are based on the error. And the final demand of China's steel in 2015 is forecasted through the combined forecasting method.
\end{abstract}

Keywords: steel demand, forecasting method, error analysis, combined forecast

\section{Introduction}

As an important basic industry of national economy, iron and steel industry provides important raw material guarantee for construction, machinery, automobiles, home appliances, shipbuilding and other downstream industries to promote the rapid development of national economy, which plays an important role in China's industrial development. With the rapid development of industrialization and urbanization in China, the steel, as an important supporting raw material, has enjoyed a rapid growth in production over the past decades. Ever since its breakthrough of 100 million tons for the first time in 1996, China's crude steel production has ranked the first in the world for 18 consecutive years. In 2013, China's crude steel output reached 779 million tons, accounting for nearly $50 \%$ of global crude steel production [1]. From 1996 to 2013, China's crude steel output grew by an average rate of $12.80 \%$ [1]. But behind the high production, iron and steel industry has to face a very serious problem of excessive production capacity. According to Economic Operation of Iron \& Steel Industry in 2013 released by Ministry of Industry and Information Technology (MIIT), China has owned existing steel production capacity of nearly 1 billion tons [2]. Guidance Opinions on Resolving Contradictions of Severe Overcapacity promulgated by The State Council pointed out that by the end of 2012, the utilization rate of China's steel production capacity was only $72 \%$, which was significantly lower than the international level [3]. In addition, explosive growth of steel production and greater steel production capacity have also brought about great pressure on resources and environment in China simultaneously when making a great contribution to national economic construction. As a result, the carbon dioxide emissions which lead to global warming from iron and steel industry become the center of people's attention. 
The development of iron and steel industry has a close connection with national economic development, and we have to face many problems urgently. For example, how much steel does China need exactly in the future, how to resolve the serious problem of excessive production capacity, how to properly deal with the relationship with the environment simultaneously when maintaining good operation in iron and steel industry and so forth. China still remains in a critical period of industrialization, and it is expected that the demand for steel of whole society will expect to continue increasing in the next period. Scientific forecast of the future demand in iron and steel industry and in-depth analysis on the future development trend of steel demand are still of great significance. At the same time, accurate prediction on the future demand for steel can play a guiding role in positioning the future development of iron and steel industry in China, and establish the definite status of iron and steel industry as the important basic industry. In addition, under the current situation of severe overcapacity of steel, grasping the trend of steel demand in the future can be favorable for us to effectively carry out the industrial layout and control the total quantity of steel production, so as to achieve the smooth digestion of production capacity and make the efficient use of resources, and thereby creating advantageous conditions for the long-term sustainable development of iron and steel enterprises. Also, many countries all over the world have committed to slow down carbon emissions in the coming future to prevent climate change [4]. As the largest industrial section of energy consumption and greenhouse gas emissions, it is necessary to figure out the trend of future steel demand.

In this paper, China's steel demand in 2015 is forecasted by making using of a combined forecasting method, which is based on the analysis of forecasting methods and their results of existing studies. The combined forecasting method includes two stages. In the first stage, with reference to actual steel demand of China in 2010, a threshold is set and some forecasting results are selected according to the error between the forecasting value and the actual value of steel demand of each method. In the second stage, weights of corresponding selected methods are determined, which are based on the error. And the final demand of China's steel in 2015 is forecasted through the combined forecasting method.

\section{Analysis on Existing Demand Forecasting Methods}

For steel demand forecast, although experts have conducted lots of researches, the methods they employed are different from each other and so are the results which even varied greatly. This part sorts and sums up the general methods of forecasting China's steel demand through the survey on steel demand forecasting methods used in the past studies, as shown in Table 1.

Table 1. Existing Steel Demand Forecasting Methods

\begin{tabular}{l|l|l|l|l}
\hline Category & \multicolumn{1}{|c|}{$\begin{array}{c}\text { Specific } \\
\text { methods }\end{array}$} & \multicolumn{1}{|c|}{$\begin{array}{c}\text { Relevant } \\
\text { literature }\end{array}$} & \multicolumn{1}{c}{ Merits and demerits } & \multicolumn{1}{c}{ Core data } \\
\hline & $\begin{array}{l}\text { Single factor } \\
\text { regression } \\
\text { analysis } \\
\text { method }\end{array}$ & $\begin{array}{l}\text { Liu Tiemin [5] } \\
\text { 2007) }\end{array}$ & $\begin{array}{l}\text { Merits: Simple and clear, easy to } \\
\text { access data. } \\
\text { Demerits: Affecting factors } \\
\text { remain too simple. }\end{array}$ & $\begin{array}{l}\text { GDP or per } \\
\text { capita GDP }\end{array}$ \\
\cline { 2 - 5 } $\begin{array}{l}\text { Mathemat } \\
\text { ical } \\
\text { model } \\
\text { method }\end{array}$ & $\begin{array}{l}\text { Multi-factor } \\
\text { regression } \\
\text { analysis } \\
\text { method }\end{array}$ & $\begin{array}{l}\text { China Iron and } \\
\text { Steel Association } \\
\text { [6](2003), Bao } \\
\text { Liang [7] (2006) } \\
\text { Zhu Jitian [8] } \\
\text { (2006), Wang Li } \\
\text { [9] (2012) }\end{array}$ & $\begin{array}{l}\text { Merits: Establishing a causal } \\
\text { relationship and considering the } \\
\text { influence of multiple factors on } \\
\text { the demand for steel. } \\
\text { Demerits: Laying too much } \\
\text { emphasis on the mathematical } \\
\text { relationship between various }\end{array}$ & $\begin{array}{l}\text { GDP, } \\
\text { population } \\
\text { structure, } \\
\text { primary } \\
\text { industry, } \\
\text { secondary } \\
\text { industry and }\end{array}$ \\
\hline
\end{tabular}




\begin{tabular}{|c|c|c|c|c|}
\hline & & & $\begin{array}{l}\text { factors and ignoring realistic } \\
\text { social factors in steel demand. }\end{array}$ & $\begin{array}{l}\text { third industry } \\
\text { output value } \\
\text { and added } \\
\text { value }\end{array}$ \\
\hline & $\begin{array}{l}\text { Grey theory } \\
\text { method }\end{array}$ & $\begin{array}{l}\text { Peng Tao, Yu } \\
\text { Yuanguan, Yan } \\
\text { Yunyun [10] ( } \\
\text { 2011) }\end{array}$ & $\begin{array}{l}\text { Merits: taking both macro and } \\
\text { micro aspects into consideration } \\
\text { and solving the uncertainty of } \\
\text { information. } \\
\text { Demerits: more complex and } \\
\text { uneasy to explain the actual } \\
\text { meaning. }\end{array}$ & $\begin{array}{l}\text { Steel } \\
\text { consumption } \\
\text { etc. }\end{array}$ \\
\hline & $\begin{array}{l}\text { Neural } \\
\text { network } \\
\text { method }\end{array}$ & $\begin{array}{l}\text { Fan Ligang[11] ( } \\
\text { 2005), Guo Juan } \\
\text { [12] (2008) } \\
\text { ZhengMinggui } \\
\text { [13] (2013) }\end{array}$ & $\begin{array}{l}\text { Merits: modeling on the basis of } \\
\text { inherent relationship between } \\
\text { data, and taking multiple } \\
\text { influencing factors into } \\
\text { consideration. } \\
\text { Demerits: Parameters of the } \\
\text { model needs to be determined by } \\
\text { iteration (beyond estimation), and } \\
\text { it is not easy for the result to } \\
\text { explain the actual meaning. }\end{array}$ & $\begin{array}{l}\text { Steel } \\
\text { consumption, } \\
\text { GDP. etc. }\end{array}$ \\
\hline & $\begin{array}{l}\text { Growth } \\
\text { curve } \\
\text { method }\end{array}$ & $\begin{array}{l}\text { Wang } \\
\text { Gaoshang[14] } \\
\text { 2002), Wu } \\
\text { Xinchun [15] } \\
\text { 2012) }\end{array}$ & $\begin{array}{l}\text { Merits: Depicting four stages of } \\
\text { things development i.e. } \\
\text { investment, growth, saturation } \\
\text { and recession, development of } \\
\text { steel in developed countries meet } \\
\text { the growth curve. } \\
\text { Demerits: Unduly relying on the } \\
\text { law of development of developed } \\
\text { countries, ignoring the } \\
\text { characteristics of its own } \\
\text { development. }\end{array}$ & $\begin{array}{l}\text { Per capita steel } \\
\text { consumption, } \\
\text { per capita GDP }\end{array}$ \\
\hline $\begin{array}{l}\text { Market } \\
\text { survey } \\
\text { method }\end{array}$ & $\begin{array}{l}\text { Sector } \\
\text { analysis } \\
\text { method }\end{array}$ & $\begin{array}{l}\text { Wei Baoren[16] ( } \\
\text { 2005), Li Ling } \\
\text { [17] (2011) } \\
\text { Yan Jianming [18] } \\
\text { (2012) }\end{array}$ & $\begin{array}{l}\text { Merits: Substantial theoretical } \\
\text { basis, accurate and intuitive } \\
\text { relatively. } \\
\text { Demerits: Need to subdivide the } \\
\text { downstream completely, higher } \\
\text { requirements for data accuracy, } \\
\text { and the error can be magnified } \\
\text { easily. }\end{array}$ & $\begin{array}{l}\text { Economic and } \\
\text { social } \\
\text { indicators } \\
\text { concerning the } \\
\text { development of } \\
\text { various } \\
\text { industries }\end{array}$ \\
\hline $\begin{array}{l}\text { Expert } \\
\text { experience- } \\
\text { based } \\
\text { method }\end{array}$ & $\begin{array}{l}\text { Expert } \\
\text { forecasting } \\
\text { method }\end{array}$ & $\begin{array}{l}\text { China Iron and } \\
\text { Steel Association } \\
\text { [6] (2003), } \\
\text { Zhang Shourong } \\
\text { [19] (2005) }\end{array}$ & $\begin{array}{l}\text { Merits: rich experience and strong } \\
\text { analytical capability. } \\
\text { Demerits: Greatly influenced by } \\
\text { subjective factors, prediction } \\
\text { results from different experts may } \\
\text { vary greatly. }\end{array}$ & $\begin{array}{l}\text { Experts' } \\
\text { judgment on } \\
\text { the industry } \\
\text { based on } \\
\text { present } \\
\text { situation and } \\
\text { the historical } \\
\text { experience of } \\
\text { the industry }\end{array}$ \\
\hline Other & $\begin{array}{l}\text { Consumptio } \\
\mathrm{n} \text { intensity } \\
\text { method }\end{array}$ & $\begin{array}{l}\text { China Iron and } \\
\text { Steel Association } \\
\text { [6] }(2003), \text { Liu } \\
\text { Tiemin [5] }(2007\end{array}$ & $\begin{array}{l}\text { Merits: the index is simple and } \\
\text { intuitive, and easy to be obtained. } \\
\text { Demerits: In case of great change } \\
\text { occurring to social and economic } \\
\text { structure, the accuracy of }\end{array}$ & $\begin{array}{l}\text { Unit economic } \\
\text { indicator, such } \\
\text { as population, } \\
\text { GDP) steel } \\
\text { consumption }\end{array}$ \\
\hline
\end{tabular}




\begin{tabular}{l|l|l|l|l}
\hline & $\begin{array}{l}\text { ）, Long Baolin } \\
{[20](2010)}\end{array}$ & prediction will be greatly reduced. & \\
\cline { 2 - 5 } & $\begin{array}{l}\text { China Iron and } \\
\text { Consumptio } \\
\text { n elasticity } \\
\text { method }\end{array}$ & $\begin{array}{l}\text { Steel Association } \\
{[6](2003)}\end{array}$ & $\begin{array}{l}\text { Merits: Simple, intuitive and } \\
\text { clear. } \\
\text { Demerits: With single index, } \\
\text { elasticity coefficient presents } \\
\text { phasic changes. }\end{array}$ & $\begin{array}{l}\text { Variation in } \\
\text { steel } \\
\text { consumption, } \\
\text { and variation in } \\
\text { GDP }\end{array}$ \\
\hline
\end{tabular}

From the specific forecasting methods described above, we find that single factor regression analysis method, consumption intensity method and consumption coefficient method are simpler than other methods. The indexes of these methods are relatively convenient to get but the consideration remains incomplete. For example, when major changes occur in social and economic structure, the forecasting results using these methods will bring larger error. As for multiple factors regression method, grey theory method, neural network method, growth curve method and sector analysis method, they give more considerations on the basis of single index. At the same time these methods take reference from the development law of other countries and explore other methods with more sufficient theory, which thereby comprehensively enriching the diversity of steel demand forecasting methods. However, the accuracy is yet to be test. Compared with other methods, expert experience method inclines to qualitative analysis and relies on experience and ability of experts. Due to different social development situations and impact from personal subjective factors, it is possible to appear larger difference between the forecasting results.

\section{Error Analysis for Forecasting Value of Steel Demand in 2010}

\subsection{Forecasting Value of China's Steel Demand in 2010}

In this section, the study conducts an error analysis of all the forecasting results in steel demand forecasting literatures. We collect the forecasting values of China's steel demand (here refers to crude steel demand) in 2010, and then compare them with the actual steel consumption in China in 2010. The forecasting values of China's steel demand in 2010 by using different methods are shown in Table 2.

\section{Table 2. Forecasting Values of China's Steel Demand in 2010 by Using Different Forecasting Methods}

\begin{tabular}{|c|c|c|c|c|}
\hline \multicolumn{2}{|c|}{ Methods } & $\begin{array}{l}\text { Base } \\
\text { year }\end{array}$ & Parameters applied & $\begin{array}{l}\text { Forecasting } \\
\text { values } \\
(100 \mathrm{Mt})\end{array}$ \\
\hline \multirow{4}{*}{$\begin{array}{l}\text { Regression } \\
\text { analysis } \\
\text { method }\end{array}$} & CISA(2003) & 2002 & $\begin{array}{l}\text { GDP, per capita GDP, building industry } \\
\text { investment and added value, per capita steel } \\
\text { consumption, etc. }\end{array}$ & 3.09 \\
\hline & $\begin{array}{l}\text { Bao } \\
\text { Liang(2006) }\end{array}$ & 2004 & $\begin{array}{l}\text { Industrial added value, the completion area of } \\
\text { building industry }\end{array}$ & 3.70 \\
\hline & $\begin{array}{l}\text { Liu } \\
\text { Tiemin(2007) }\end{array}$ & 2004 & GDP & 4.50 \\
\hline & $\begin{array}{ll}\begin{array}{l}\text { Zhu } \\
(2006)\end{array} & \text { Jitian } \\
\end{array}$ & 2004 & GDP, GDP growth rate & 5.10 \\
\hline $\begin{array}{l}\text { Grey theory } \\
\text { method }\end{array}$ & Peng Tao(2011) & 2008 & GDP & 4.98 \\
\hline $\begin{array}{l}\text { Neural } \\
\text { network }\end{array}$ & $\begin{array}{l}\text { Fan } \\
\text { Ligang(2005) } \\
\end{array}$ & 2003 & GDP, GDP growth rate & 4.47 \\
\hline
\end{tabular}




\begin{tabular}{l|l|l|l|c}
\hline method & & & & \\
\hline $\begin{array}{l}\text { Growth } \\
\text { curve } \\
\text { method }\end{array}$ & $\begin{array}{l}\text { Wang } \\
\text { Gaoshang(2002) }\end{array}$ & 2002 & Per capita GDP, per capita consumption & 2.54 \\
\cline { 2 - 5 } & $\begin{array}{l}\text { Liu } \\
\text { Tiemin(2007) }\end{array}$ & 2004 & GDP & 4.10 \\
\hline \multirow{2}{*}{$\begin{array}{l}\text { Sector } \\
\text { analysis } \\
\text { method }\end{array}$} & $\begin{array}{l}\text { Wei } \\
\text { Baoren(2005) }\end{array}$ & 2002 & $\begin{array}{l}\text { Divided into three sectors, employing } \\
\text { population, building area, and other related } \\
\text { parameters }\end{array}$ & 2.65 \\
\cline { 2 - 6 } & CISA(2003) & 2002 & $\begin{array}{l}\text { Divided into eight sectors, employing } \\
\text { building area, auto mobile production and } \\
\text { other related parameters }\end{array}$ & 3.30 \\
\hline $\begin{array}{l}\text { Expert } \\
\text { forecasting } \\
\text { method }\end{array}$ & CISA(2003) & 2002 & - & 2.87 \\
\hline $\begin{array}{l}\text { Consumption } \\
\text { intensity } \\
\text { method }\end{array}$ & Shourong(2005) & 2004 & - & Long \\
\hline $\begin{array}{l}\text { Consumption } \\
\text { elasticity } \\
\text { method }\end{array}$ & CISA(2003) & 2002 & $\begin{array}{l}\text { Elasticity coefficient } \\
\text { Between steel consumption and GDP }\end{array}$ & 2.54 \\
\hline
\end{tabular}

It can be seen from table 2 that the results differ from each other widely. Previous studies mainly applied regression analysis method to forecast, but the forecasting results were not the same even when employing the same kind of forecasting method. This may be due to such factors as different base year of forecasting, various variables chosen in respective regression methods and so on. Grey theory method and neural network method were rarely used, but the forecasting results of the two methods were still in the upper level in all the predicted results. The forecasting results of growth curve method also show that the results can be different even using the same method. The forecasting results of sector analysis method and expert experience forecasting method proved relatively lower than other methods. Sector analysis method requires a complete classification of downstream of steel industry, otherwise it is easy to cause lower forecasting result caused by incomplete coverage. However, experts' forecast is mostly based on the law of development in the past. The increment of annual steel output was less than 10 million tons before 2001, so the development condition at that time might exert an effect on subjective judgment. Forecasting value of consumption intensity method was the highest among all the values, while the value of consumption elasticity method is the lowest.

Actually, in 2010, China realized its crude steel production of 639 million tons. With 16.43 million tons of steel imported and 42.56 million tons exported, the net steel export was 26.13 million tons which was equivalent to about 27.8 million tons of net export of crude steel. As a result, we could infer that the actual consumption of crude steel was 611 million tons in 2010[1].

By comparing forecasting values for 2010 made by above methods with the actual value of crude steel consumption in 2010, it can be seen that all forecasts are lower than the actual value in the current year. It is obviously that even forecasting methods with available mature scientific theoretical basis cannot achieve totally accurate predictions. 


\subsection{Deviation Rate from Actual Value in 2010}

Further analysis between forecasting value and actual value of crude steel demand in 2010 is conducted below and we can get the deviation degree of forecasting value of each method from actual demand, as shown in Table 3.

\section{Table 3. Deviation Rate between the Forecasting Value and Actual Value in 2010}

\begin{tabular}{|c|c|c|c|c|}
\hline \multicolumn{2}{|c|}{ Methods } & $\begin{array}{l}\text { Forecasting } \\
\text { values in } \\
2010(100 \mathrm{Mt})\end{array}$ & $\begin{array}{l}\text { Actual values in } \\
2010(100 \mathrm{Mt})\end{array}$ & $\begin{array}{c}\text { Deviation Rate } \\
\text { from Actual } \\
\text { Value in } \\
2010(\%)\end{array}$ \\
\hline \multirow{4}{*}{$\begin{array}{l}\text { Regression analysis } \\
\text { method }\end{array}$} & CISA(2003) & 3.09 & \multirow{14}{*}{6.11} & 49.43 \\
\hline & Bao Liang(2006) & 3.70 & & 39.44 \\
\hline & Liu Tiemin(2007) & 4.50 & & 26.35 \\
\hline & Zhu Jitian (2006) & 5.10 & & 16.53 \\
\hline Grey theory method & Peng Tao(2011) & 4.98 & & 18.49 \\
\hline $\begin{array}{l}\text { Neural network } \\
\text { method }\end{array}$ & Fan Ligang(2005) & 4.47 & & 26.84 \\
\hline \multirow{2}{*}{$\begin{array}{l}\text { Growth curve } \\
\text { method }\end{array}$} & $\begin{array}{l}\text { Wang } \\
\text { Gaoshang(2002) }\end{array}$ & 2.54 & & 58.43 \\
\hline & Liu Tiemin(2007) & 4.10 & & 32.90 \\
\hline \multirow{2}{*}{$\begin{array}{l}\text { Sector analysis } \\
\text { method }\end{array}$} & Wei Baoren(2005) & 2.65 & & 56.63 \\
\hline & CISA(2003) & 3.30 & & 45.99 \\
\hline \multirow{2}{*}{$\begin{array}{l}\text { Expert forecasting } \\
\text { method }\end{array}$} & CISA(2003) & 2.87 & & 53.03 \\
\hline & $\begin{array}{l}\text { Zhang } \\
\text { Shourong(2005) }\end{array}$ & 2.54 & & 58.43 \\
\hline $\begin{array}{l}\text { Consumption } \\
\text { intensity method }\end{array}$ & Long Baolin(2010) & 5.18 & & 15.22 \\
\hline $\begin{array}{l}\text { Consumption } \\
\text { elasticity method }\end{array}$ & CISA(2003) & 2.80 & & 54.17 \\
\hline
\end{tabular}

Select the best forecasting result from each method to get the Table 4 . We can see that the forecasting value of consumption intensity method has minimum deviation rate of $15.22 \%$ from the actual value followed by regression method (16.53\%). Gray theory method ranks the third with the deviation rate of $18.49 \%$. The deviation rates of other forecasting methods are higher and some rates even exceed $50 \%$.

Table 4. Best Result of Each Method in 2010

\begin{tabular}{|c|c|c|c|c|}
\hline \multicolumn{2}{|c|}{ Methods } & $\begin{array}{l}\text { Forecasting } \\
\text { values in } \\
\end{array}$ & $\begin{array}{l}\text { Actual values in } \\
2010(100 \mathrm{Mt})\end{array}$ & $\begin{array}{l}\text { Deviation from } \\
\text { Actual Value in }\end{array}$ \\
\hline $\begin{array}{l}\text { Regression analysis } \\
\text { method }\end{array}$ & Zhu Jitian (2006) & 5.10 & \multirow{5}{*}{6.11} & 16.53 \\
\hline Grey theory method & Peng Tao(2011) & 4.98 & & 18.49 \\
\hline $\begin{array}{l}\text { Neural network } \\
\text { method }\end{array}$ & Fan Ligang(2005) & 4.47 & & 26.84 \\
\hline $\begin{array}{l}\text { Growth curve } \\
\text { method }\end{array}$ & Liu Tiemin(2007) & 4.10 & & 32.90 \\
\hline $\begin{array}{l}\text { Sector analysis } \\
\text { method }\end{array}$ & CISA(2003) & 3.30 & & 45.99 \\
\hline
\end{tabular}




\begin{tabular}{l|l|c|c|c}
\hline $\begin{array}{l}\text { Expert forecasting } \\
\text { method }\end{array}$ & CISA(2003) & 2.87 & \multirow{5}{*}{} & 53.03 \\
\hline $\begin{array}{l}\text { Consumption } \\
\text { intensity method }\end{array}$ & Long Baolin(2010) & 5.18 & & 15.22 \\
\hline $\begin{array}{l}\text { Consumption } \\
\text { elasticity method }\end{array}$ & CISA(2003) & 2.80 & & 54.17 \\
\hline
\end{tabular}

It should be noted that China is in the stage of rapid development of industrialization and urbanization and the development speed of China's steel industry is well beyond our imagination. Developed countries, such as United States, attained steel production peak at 136 million tons, and Japan peaked its steel output at 119 million tons. However, China exceeded 200 million tons in 2003. As a big country of iron and steel production and consumption, China is not necessarily expected to have such an amazing development speed in steel production in recent years especially since 2001 even if we make any audacious forecast on the development of steel industry ten or even five years ago. In addition, whether it is due to the rapid development of industrialization and urbanization or strong support from economic investment in the past, China's steel demand in the past few decades was in a special developing stage, and the steel production achieved amazing growth. However, our forecast by various methods gave no or less consideration to the effects of these special factors, leading to lower forecasting values. Next, a lot of researches and reports including $12^{\text {th }}$ Five-year Development plan of Iron \& Steel Industry maintain that China's demand for crude steel may step into peak area during "twelfth five-year" and the development of iron and steel industry will be gradually stabilized. So the deviation will be reduced if using the same methods to forecast in this case. Thus, it is inappropriate to simply think that these forecasting methods cannot forecast the future steel demand.

However, there are still risks when using one method alone to forecast the future demand. That is to say we may lose some useful information of one method when we actually use another one to forecast. Each method has its own merits and demerits and each of them can provide favorable information from a different perspective [21]. As early as 1969, Bates J.M. and Granger C.W.J. [22] firstly proposed a concept -"combination forecasting" which was considered reasonable. This approach requires considering the characteristics of each individual forecasting method, and then combining every individual forecasting method to get the final result. $\mathrm{Wu}$ Wendong [23] used a combined forecasting model based on correlation coefficient to forecast the future steel demand, which took the regression method, gray theory and neural network method into consideration. Gan Lin [24] forecasted the long-term electricity demand also by using a combined forecasting model.

Thus, in order to better carry out scientific forecast, this paper employs the combined forecasting model to forecast the steel demand of 2015 on the basis of existing research on the forecasting method.

In order to make more scientific forecast, on the basis of the existing methods, this paper conducts the forecast of China's steel demand of 2015 through the combined forecasting method. For instance, combining three methods with deviation rate lower than $20 \%$ (consumption intensity method, regression analysis method and gray theory method) and simultaneously completing correction term adjustment, and we finally forecast the China's steel demand in 2015. 


\section{Combined forecast on China's Steel Demand in 2015}

This section presents the combined forecasting model of steel demand in 2015. The forecasting result $(\mathrm{F})$ is made up of basic combined forecasting value and correction term. The formulation is shown as follows.

$$
F=F_{B}+\Delta F
$$

Where, $F_{B}$ means basic combined forecasting value, and $\Delta F$ represents correction term. Specific steps of the combined forecasting method are presented in the following.

\section{Step1: Set Threshold and Select Signal Forecasting Method}

It is necessary to set a parameter for selecting predicted methods used in the combined forecasting model. Set the threshold $\theta$ from $0 \%$ to $100 \%$, which means the highest acceptance of deviation rate between the forecasting value and actual value in 2010. According to the best forecasting result of each method and actual value of 2010, if computed deviation rate between them is lower than $\theta$, then it is chosen.

In this paper, the threshold $\theta$ is chosen as 20 percent. Then methods used in the combined forecasting model are picked up by comparing threshold and deviation rate. The selected results (methods) are shown in Table 5.

Table 5. Selected Results (Methods)

\begin{tabular}{lccc}
\hline Methods & $\begin{array}{c}\text { Forecasting values } \\
\text { in 2010(100 Mt) }\end{array}$ & $\begin{array}{c}\text { Actual values } \\
\text { in 2010(100 } \\
\mathrm{Mt})\end{array}$ & $\begin{array}{c}\text { Deviation Rate from } \\
\text { Actual Value in } \\
2010(\%)\end{array}$ \\
\hline $\begin{array}{l}\text { Consumption intensity } \\
\text { method }\end{array}$ & 5.18 & & 15.22 \\
$\begin{array}{l}\text { Regression method } \\
\text { Grey theory method }\end{array}$ & 5.10 & 6.11 & 16.53 \\
\hline
\end{tabular}

\section{Step2: Determine the Weight of Basic Combined Forecasting Value}

Calculate the proximity of the forecasting values of 2010 made by consumption intensity method, regression analysis method and gray theory method to the actual values (forecasting value /actual value, as Table 6 shows), then conduct normalized processing to get the weights of these three methods, namely $0.339,0.334$ and 0.339 respectively. The calculation process of weight is shown in Table 6.

Table 6. Determining Weight of Three Methods

\begin{tabular}{lccc}
\hline Methods & $\begin{array}{c}\text { Forecasting values in } \\
\text { 2010(100Mt) }\end{array}$ & $\begin{array}{c}\text { Forecasting value } \\
\text { /actual value }\end{array}$ & Weights \\
\hline Consumption intensity & 5.18 & 0.848 & 0.339 \\
method & 5.10 & 0.835 & 0.334 \\
Regression method & 4.98 & 0.815 & 0.326 \\
Grey theory method &
\end{tabular}

\section{Step3: Calculate Basic Combined Forecasting Value}

Calculate basic combined forecasting value according to the following model:

$$
F_{B}=\sum_{i=1}^{3} w_{i} F_{i}
$$


Where $w_{i}$ means the weight of consumption intensity method, regression and gray theory method respectively, and $F_{i}$ represents the forecasting value of China's steel demand in 2015 by applying above three methods.

The same literatures, which have employed above three methods to forecast China's steel demand of 2010, figure out the forecasting values of 2015, respectively as follows: 627 million tons, 766 million tons and 730 million tons.

The calculation process is shown in Table 7 .

Table 7. Forecasting Result of Basic Combined Forecast in 2015

\begin{tabular}{|c|c|c|c|}
\hline Methods & $\begin{array}{l}\text { Forecasting values } \\
\text { in } 2015(100 \mathrm{Mt})\end{array}$ & Weights & $\begin{array}{c}\text { Forecasting value of basic } \\
\text { combined forecast in } \\
2015(100 \mathrm{Mt})\end{array}$ \\
\hline $\begin{array}{l}\text { Consumption intensity } \\
\text { method }\end{array}$ & 6.27 & 0.339 & \multirow{3}{*}{7.07} \\
\hline Regression method & 7.66 & 0.334 & \\
\hline Grey theory method & 7.30 & 0.326 & \\
\hline
\end{tabular}

According to each forecasting value of 2015 and respective weight coefficient of consumption intensity method, grey theory method and regression analysis method, it is concluded that the basic combined forecasting value of China's steel demand in 2015 is 707 million tons.

\section{Step4: Calculate Correction Term}

Error analysis shows that there are some deviations to some extent when using those methods respectively. In order to reduce the deviation between the forecasting values and actual values, we need to adjust the basic combined forecasting value of steel demand in 2015.

Calculate correction term according to the following model:

$$
\Delta F=\alpha F_{B}
$$

Where, $\alpha$ represents weighted deviation rate. It is calculated by the following formula: $\alpha=\sum_{i=1}^{3} w_{i} \alpha_{i}$.

Result shows that the weighted deviation rate is $16.72 \%$, then it is calculated that correction term is 118 million tons.

\section{Step5: Calculate Eventual Forecasting Vvalue of China's Steel Demand in 2015}

Finally, the eventual forecasting value of China's steel demand in 2015 is 825 million tons according to the formula (1).

\section{Conclusions}

Steel demand forecasting is very important for the future development of iron and steel industry of China. There is not yet an accepted systematic method available for effective and accurate analysis of national macro steel demand or consumption.

By means of investigating a great deal of literatures concerning steel demand forecasting, some general methods of steel demand forecasting are firstly summed up and both the merits and demerits of these methods are analyzed. Secondly, error analysis is conducted for predicted values of steel demand in 2010 in these literatures. Then three methods including 
consumption intensity method, regression analysis method and gray theory method are selected out by setting a threshold. After that, the corresponding literatures that apply the same three methods to predict steel demand are once again sorted and give the range of China's steel demand in 2015 which is between 627 million tons and 766 million tons.

On this basis, the weight according to the proximity between actual values and predicted values of these three methods is determined, and basic combined forecasting value is calculated. Furthermore, weighted deviation of these three methods is used as correction term, and finally the study draws a conclusion that China's steel demand in 2015 will be 825 million tons.

Iron and steel industry is an intensive industry with high consumption of energy and resource, its development not only concerns the development of steel industry itself, but also involves many upstream and downstream industries, and even affects the operation of the whole social economy. In other words, the term "sustainability" means taking a holistic view of environmental and economic impact [25]. Further advancement of industrialization and urbanization needs strong support from iron and steel industry, but now China's steel industry overcapacity problem is already very serious, which is not conducive to the sustainable development of iron and steel enterprises. To achieve accurate prediction on development of iron and steel industry in the future, we not only need to improve the existing method proved effective, but also shall make theory innovation, and explore new methods by combining with practical circumstances of China. "Twelfth five-year" period is not only a crucial phase for further promoting scientific development, accelerating transformation of development modes, but also a critical period of industrialization and urbanization, thus we should reasonably guide the market to realize optimal allocation of resources, speed up product upgrading, orderly close down backward production facilities, strengthen technical innovation and technological transformation, and finally realize green sustainable development of iron and steel industry.

\section{Acknowledgments}

This study is funded by the National Natural Science Foundation of China (Grant NO.71373142).

\section{References}

[1] China Iron and Steel Association, China Steel Yearbook. Metallurgy Industry Press, (2013), Beijing.

[2] Ministry of Industry and Information Technology, Economic Operation of Iron \& Steel Industry in 2013.http://www.chinasie.org.cn/news_info.aspx?id=179920\&lei01=2, (2013).

[3] State Council, Guidance Opinions on Resolving Contradictions of Severe Overcapacity, (2013).

[4] S. Tang, W. Wang and S. Cho, "Reduction Carbon Emissions in Supply Chain through Logistics Outsourcing", Journal of System and Management Sciences, vol. 4, no. 01, (2014), pp. 10-15.

[5] T. Liu, "Econometric Prediction on Crude Steel and Iron Ore Demand in China", Northeastern University, Shenyang Liaoning, (2007).

[6] China Iron and Steel Association, The Steel Market Demand Forecast and a Number of Recommendations of the Iron and Steel Industry Development Strategy. China Steel, vol. 1, no. 01, (2003), pp. 05-11

[7] L. Bao and W. Xi, "Study on Analysis of Steel Demand in China", Science and Technology and Economy, vol. 04, (2006), pp. 2-6.

[8] J. Zhu and T. Hong, "Forecast of China's Steel Demand and Countermeasures for Security Supply of Iron Ore Resource", Metal Mine, vol. 1, no. 10, (2006), pp. 09-12.

[9] L. Wang, "Prediction of the Long-term Demand for Iron and Steel Resources in China", Geology and exploration, vol. 48, no. 6, (2012), pp. 1129-1133.

[10] T. Peng, Y. She and Y. Yan, "Prediction Study on Steel Demand of China Based on Cointegration and Grey System Theory", Mathematics in Practice and Theory, vol. 41, no. 10, (2011), pp. 102-108. 
[11] L. Fan, "Research on Long-term Demand of Steel and Iron of China Forecast", Northeastern University, Shenyang Liaoning, (2005).

[12] J. Guo, "China's Iron Ore Demand Prediction Based on BP Neural Network", Mineral Resources, vol. 11, (2008), pp. 41-44.

[13] M. Zheng and W. Xie, "Demand Scenario Analysis of Iron Ore Minerals in China Based on BP Neural Network", Metal Mine, vol. 03, (2013), pp. 57-61.

[14] G. Wang, "The Prediction of the Demand on Important Mineral Resources in China", Acta Geoscientia Sinica, vol. 23, no. 06, (2002), pp. 483-490.

[15] X. Wu, "Prediction of Iron \& Steel Demand in China in 2015", Wisco Technology, vol. 50, no. 2, (2012), pp. $1-3$.

[16] B. Wei and H. Y. Gita, "Forecast of Yearly Production and Energy Demand in Chinese Steel Industry", China Metallurgy, vol. 15, no. 12, (2005), pp. 14-17.

[17] L. Li, "Research on the Carbon-footprint in China Iron and Steel Industry Based on System Dynamics", Metallurgical Industry Automation, vol. 35, no. 6, (2011), pp. 7-10.

[18] J. Yan, G. Pu, Z. Liu and Y. Shi, "Study on Needs Prediction Model in Steel Industry Based on Different Levels", Science and Technology Management Research, vol. 18, (2012), pp. 254-258.

[19] S. Zhang, "How to Take a New Road of Industrialization of China's Steel Industry", Macroeconomic Study, vol. 05, (2005), pp. 17-20.

[20] B. Long and J. Ye, "China's Steel and Iron Ore Demand Forecast Study”, China Mining Magazine, vol. 19, no. 11, (2010), pp. 04-06.

[21] H. Dai, "Research on Combination Forecasting Model and its Application", Central South University, Changsha Hunan, (2007).

[22] J. M. Bates and W. J. Granger Clive, "The Combination of Forecasts”, Operational Research Quarterly, vol. 20, no. 4, (1969), pp. 451-468.

[23] W. Wu, G. Wu, Y. Wei and Y. Fan, "Combined Forecasting Models of Steel Demand Based on Correlation Coefficients", Chinese Journal of Management Science, vol. 16, (2008), pp. 45-49.

[24] L. Gan, "Application of Combination Forecast Model in the Medium and Long Term Power Load Forecast", Nanchang Hangkong University, Nanchang Jiangxi, (2012).

[25] T. Baines, S. Brown, O. Benedettini and P. Ball, "Examining Green Production and Its Role within the Competitive Strategy of Manufacturers", Journal of Industrial Engineering and Management, vol. 5, no. 01, (2012), pp. 53-87. 
International Journal of $u$ - and e- Service, Science and Technology Vol.8, No.1 (2015) 